\title{
Gas-Phase Photocatalytic Oxidation: Cost Comparison with Other Air Pollution Control Technologies
}

Craig S. Turchi

Edward J. Wolfrum

National Renewable Energy Laboratory

Richard A. Miller

IT Corporation

Presented at Advanced Oxidation

Technologies for Water and Air

Remediation, London, Ontario, Canada, June 25-30, 1994

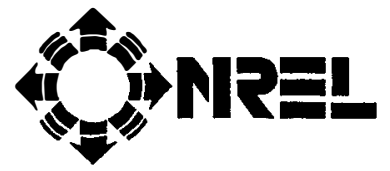

National Renewable Energy Laboratory

1617 Cole Boulevard

Golden, Colorado 80401-3393

A national laboratory of the U.S. Department of Energy managed by Midwest Research Institute for the U.S. Department of Energy under Contract No. DE-AC36-83CH10093

November 1994 


\section{NOTICE}

This report was prepared as an account of work sponsored by an agency of the United States government. Neither the United States government nor any agency thereof, nor any of their employees, makes âny warranty, express or implied, or assumes any legal liability or responsibility for the accuracy completeness, or usefulness of any information, apparatus, product, or process disclosed, or represents that its use would not infringe privately owned rights. Reference herein to any specific commercial product, process, or service by trade name, trademark, manufacturer, or otherwise does not necessarily constitute or imply its endorsement, recommendation, or favoring by the United States government or any agency thereof. The views and opinions of authors expressed herein do not necessarily state or reflect those of the United States government or any agency thereof.

Available to DOE and DOE contractors from:

Office of Scientific and Technical Information (OSTI)

P.O. Box 62

Oak Ridge, TN 37831

Prices available by calling (615) $576-8401$

Available to the public from:

National Technical Information Service (NTIS)

U.S. Department of Commerce

5285 Port Royal Road

Springfield, VA 22161

(703) $487-4650$ 


\title{
Gas-Phase Photocatalytic Oxidation: Cost Comparison with Other Air Pollution Control Technologies
}

\author{
Craig S. Turchi and Edward J. Wolfrum \\ National Renewable Energy Laboratory \\ Golden, Colorado, USA
}

\author{
Richard A. Miller \\ IT Corporation \\ Knoxville, Tennessee, USA
}

\author{
NREL/TP-471-7014, Presented at: \\ Advanced Oxidation Technologies for Water and Air Remediation \\ London, Ontario, Canada, June 25-30, 1994
}

\begin{abstract}
Gas-phase photocatalytic oxidation (PCO) appears to be particularly well suited for waste streams with low pollutant concentrations (1000 ppm or less) and low to moderate flow rates $(<20,000$ cubic feet per minute, cfm). The PCO technology is modular in nature and thus is well suited to treat dispersed or low flow rate streams. This same attribute minimizes the advantages of scale for PCO and makes the technology comparatively less attractive for high volume waste streams. Key advantages for PCO lie in its low operating cost and ability to completely destroy pollutants at ambient temperature and pressure.
\end{abstract}

\section{Introduction}

The photocatalytic oxidation process destroys organic air pollutants at ambient temperature and pressure through the use of a light-excited titanium dioxide catalyst [1,2]. The National Renewable Energy Laboratory (NREL), International Technology Corporation (IT), and other industrial partners are currently developing this process for the treatment of industrial emissions, site remediation [3], and indoor air quality. The objective of our study is to compare PCO costs to those for other common means of treating volatile organic compounds (VOCs) in air.

\section{Method}

In late 1992, the American Institute of Chemical Engineers (AIChE) Center for Waste Reduction Technologies completed a study on VOC control technologies [4]. Also, a recent issue of Chemical Engineering Progress dealt with the question of air pollution control [5]. In completing the present study, we endeavored to duplicate the costing and evaluation methods of the AIChE reports. Thus the PCO process was compared on the same terms as the other technologies. It is important to remember that, while costs for the other technologies are based on full-scale commercial systems and prices, data on commercial PCO systems are not yet available and PCO costs are estimates based on data obtained from laboratory and pilot-scale systems.

The core of this report is a list of key assumptions (Table 1) and the display of the major 
findings (Table 2). Most of the content of Table 2 was taken from reference [5]. We added the last two rows to provide a comparison of the PCO process. As shown, costs for air pollution control equipment are typically quoted as $\$ / \mathrm{cfm}$, emphasizing the strong effect stream flow rate has on system cost.

Table 1: Assumed Values for Determining Photocatalytic Oxidation (PCO) Costs.

\begin{tabular}{|c|c|c|}
\hline Variable & Assumed Value & Reference \\
\hline Photoefficiency & $10 \%$ at $100 \mathrm{ppm} \mathrm{VOC}$ & {$[9],[10]$} \\
\hline Effective solar ultraviolet intensity & $10 \mathrm{~W} / \mathrm{m}^{2}$ & [5] \\
\hline Solar system equipment cost & $\$ 200 / \mathrm{m}^{2}$ & [3] \\
\hline Lamp ultraviolet efficiency & $25 \% \mathrm{~W}_{\mathrm{UV}}$ per $\mathrm{W}_{\text {electric }}$ & \\
\hline Lamp system equipment cost $(\$ 000)$ & $1.0 *(\mathrm{~kW})+30$ & [7] \\
\hline Electrical energy cost & $\$ 0.06 / \mathrm{kWh}$ & \\
\hline Capital cost factor* & 1.61 & [4] \\
\hline Indirect Annual Costs & $6 \%$ of total capital cost & [4] \\
\hline Direct Annual Labor & $\$ 14,600$ & [4] \\
\hline Direct Annual Materials & $2 \%$ of total capital cost & [4] \\
\hline
\end{tabular}

* Total capital cost $=($ purchased equipment cost $) \times($ capital cost factor $)$

The final capital and annual operating costs shown in Table 2 reflect the use of each system at the extremes of applicable concentration and capacity ranges. The PCO costs were projected for systems ranging from $250 \mathrm{cfm}$ to $20,000 \mathrm{cfm}$. While the technology can easily treat lower flow rates, the current costing method is not suitable for very small systems. The lamp equipment cost formula shown in Table 1 is consistent with the cost of the $250 \mathrm{cfm}$ PCO pilot unit built by IT Corporation. Levelized annual costs were computed by multiplying the capital cost by a fixed charge rate of $16.28 \%$ (10-year life assumed) and adding this capital recovery cost to the other annual costs [4].

Using the above assumptions, the costs for the PCO systems were generated by examining several hypothetical applications varying in flow volume, VOC concentration, and photoefficiency. This analysis showed that cost per cfm increased with VOC concentration but was relatively insensitive to flow rate. For VOC concentrations above about 1000 ppm, costs for the PCO system were deemed too expensive relative to other technologies. Thus the upper bound on the applicable concentration range was set at $1000 \mathrm{ppm}$. PCO costs per cfm are relatively insensitive to flow rate, whereas $\$ / \mathrm{cfm}$ costs for other technologies tend to decrease with increasing flow volume, as shown in Figure 1. Incineration costs display a similar lack of sensitivity to flow rate at higher flows. These trends indicate that the relative advantage of PCO lies at lower flow rates, and the value of $20,000 \mathrm{cfm}$ was selected as the upper bound. It should be noted that the conditions depicted in Figure 1 put PCO at a relative disadvantage compared to the other treatment technologies. This occurs because a hydrocarbon pollutant is easily incinerated, adsorbed, or biodegraded, but is only moderately reactive in the PCO system. In contrast, chlorinated compounds, particularly chlorinated ethylenes such as TCE, are particularly 
well suited for PCO treatment. These compounds degrade rapidly in PCO systems but are difficult to treat by other means. Additionally, by running at ambient temperatures, PCO systems can be constructed with plastic materials and acid gas products like $\mathrm{HCl}$ pose no corrosion problems.

Naturally, PCO cost was highly sensitive to photoefficiency. For this analysis we assumed a photoefficiency of $10 \%$ ( 0.10 moles VOC destroyed per einstein UV incident) at an initial VOC concentration of $100 \mathrm{ppm}$. This value is consistent with published reports [9] and internal NREL data [10]. Some chlorinated compounds display even faster reaction rates. Photoefficiencies in excess of $100 \%$ (presumably due to radical chain reactions) have been reported for TCE. For TCE and similar compounds, the costs for the PCO process will be lower than those shown in Figure 1 and Table 2. Lastly, photoefficiency was assumed to increase with VOC concentration as seen in laboratory studies. The functionality of the dependence was taken from data published by ClearFlow for the destruction of TCE in air [9].

\section{Results and Conclusions}

The estimated costs and performance ranges for the PCO technology are based on laboratory data, pilot-scale tests, and engineering estimates. Although these data are less accurate than information from commercially operating systems, they are sufficient to identify the following trends pertaining to the relative merits of the PCO technology.

First, photocatalytic oxidation appears to be best suited for low concentration (1000 ppm or less) waste streams. This is partially due to the strong dependence of PCO cost on VOC concentration and partially due to the suitability of product recovery technologies (such as condensation) to high-concentration waste streams. Based on this fact and on common concerns regarding oxidation products and catalyst fouling, PCO can be most easily compared to catalytic oxidation. Thus when looking at potential applications, likely market size, and probable competitors of the photocatalytic process, current thermal catalytic oxidation serves as a good role model.

Second, as a modular technology, the advantages of PCO are most apparent on low- to moderatevolume streams. The modular nature of PCO offers the advantage of system flexibility. However, this same attribute prevents PCO from benefitting from economies of scale like most of the other air pollution control technologies. Thus, while PCO costs normalized as \$/cfm remain relatively constant as flow rate increases, the normalized costs for the competing technologies drop. Conversely, the modular nature of PCO designs, much like carbon canisters, is a key advantage when treating smaller flow rate streams. Given that surveyed users expect $80 \%$ of their expenditures for VOC control systems to be for low-flow-rate streams $(<5000 \mathrm{cfm})$ [4], PCO systems could make significant inroads into this market.

When compared to the other technologies, PCO generally has similar or slightly higher capital costs. The major benefit of PCO arises from its lower operating costs. The PCO process has the lowest operating costs of any of the VOC control technologies. IT Corporation has stated that the low operating cost of the PCO technology has been a major selling point with interested users [8]. Largely because of these low operating costs, when levelized annual costs are examined, both the solar and lamp PCO processes have cost advantages over the other destructive technologies for the specified range of conditions. As depicted in Figure 1, the cost advantage 
of PCO is most apparent on low flow rate streams.

Under the current assumptions, levelized annual costs for the electric and solar PCO systems are roughly equal (see Figure 2). Of course, the solar technology must deal with limited system availability due to weather and nightfall. These restraints make solar units best suited for applications where daylight operation is sufficient, averaged emission levels are more important than temporal levels, and electricity is expensive or not available. A good example of an application favorable to solar is a site with emissions during an 8-to-5 work shift and regulatory requirements based on total annual emissions. Such applications are not uncommon, particularly with small emitters. Other possible solar applications include remote sites, storage tank vents, or potentially explosive waste streams.

One promising application for a solar system is the regeneration of a carbon bed or other adsorbent [11,12]. In this application, the adsorbent does the 24-hr VOC removal work, and the solar system is used to purge and destroy the contaminants during daylight hours. By minimizing the required capacity of both units, a combined system could be less expensive than either process used individually.

\section{References}

[1] Dibble, L.A., and G.B. Raupp, Environ. Sci. Technol., Vol. 26, No. 3, 1992.

[2] Nimlos, M.R., W.A. Jacoby, D.M. Blake, and T.A. Milne, Environ. Sci. Technol., Vol. 27, No. 4, 1993.

[3] Turchi, C.S., E.J. Wolfrum, and M.R. Nimlos, Cost Estimation for Treating VOCs in an Airstripper Offgas with Gas-Phase Photocatalysis, NREL/TP-471-5782, October 1993.

[4] AIChE Center for Waste Reduction Technologies, Current and Potential Future Industrial Practices for Reducing and Controlling Volatile Organic Compounds, American Institute of Chemical Engineers, New York, September 1992.

[5] "Air Pollution Control," Chem. Engrg. Prog., Vol. 89, No. 7, 19-41, (1993).

[6] Mehos, M., K. Pacheco, and H. Link, Measurement and Analysis of Near Ultraviolet Solar Radiation, NREL/TP-253-4493, December 1991.

[7] Notarfonzo, R. and W. McPhee, "How to Evaluate a UV/Oxidation System," Pollution Engineering, 74-76, October 1994.

[8] Miller, R. and R. Fox, "Treatment of Organic Contaminants in Air by Photocatalytic Oxidation: A Commercialization Perspective," in Photocatalytic Purification and Treatment of Water and Air, D.F. Ollis and H. Al-Ekabi, Eds., Elsevier, 1993.

[9] Berman, E., and J. Dong, "Photocatalytic Decomposition of Organic Pollutants in Gas Streams," Proceedings from Chemical Oxidation, Technologies for the Nineties, Nashville, TN, February 17-19, 1993.

[10] Nimlos, M.R., internal NREL data, 1993. Report in progress.

[11] Glatzmaier, G., Cost Comparison of Solar Detoxification with Conventional Alternatives for the Destruction of Trichloroethylene, NREL/TP-253-4491, December 1991.

[12] Notthakun, S., J. Crittenden, D. Hand, D. Perram, and M. Mullins, "Regeneration of Adsorbents Using Heterogeneous Advanced Oxidation," J. Environ. Engng., Vol. 119, No. 4, July/August 1993. 
Table 2: Summary of Air Pollution Control Technologies. Table format and the first five rows taken directly from Reference [5].

\begin{tabular}{|c|c|c|c|c|c|c|c|c|c|}
\hline $\begin{array}{l}\text { Control } \\
\text { Technology }\end{array}$ & $\begin{array}{l}\text { Applicable } \\
\text { Concen. } \\
(\mathrm{ppm})\end{array}$ & $\begin{array}{l}\text { Capacity } \\
\text { Range, } \\
(\mathrm{cfm})\end{array}$ & $\begin{array}{l}\text { Removal } \\
\text { Efficiency } \\
(\%)\end{array}$ & $\begin{array}{l}\text { Capital } \\
\text { Cost, } \\
(\$ / \mathrm{cfm})\end{array}$ & $\begin{array}{l}\text { Annual } \\
\text { Operating } \\
\text { Cost }(\$ / \mathrm{cfm})\end{array}$ & $\begin{array}{l}\text { Levelized } \\
\text { annual cost, } \\
(\$ / \mathrm{cfm})\end{array}$ & $\begin{array}{l}\text { Secondary } \\
\text { Wastes }\end{array}$ & Advantages & $\begin{array}{l}\text { Limitations and } \\
\text { Contraindications }\end{array}$ \\
\hline $\begin{array}{l}\text { Thermal } \\
\text { Oxidation }\end{array}$ & $100-2000$ & $\begin{array}{l}1000- \\
500,000\end{array}$ & $95-99+$ & $\begin{array}{l}\text { recuperative } \\
10-200 \\
\text { regenerative } \\
30-450\end{array}$ & $\begin{array}{l}\text { recuperative } \\
15-90 \\
\text { regenerative } \\
20-150\end{array}$ & $\begin{array}{l}\text { recuperative } \\
17-120 \\
\text { regenerative } \\
25-220\end{array}$ & $\begin{array}{l}\text { Combustion } \\
\text { products }\end{array}$ & $\begin{array}{l}\text { Up to } 95 \% \text { energy } \\
\text { recovery is possible }\end{array}$ & $\begin{array}{l}\text { Halogenated compounds may require } \\
\text { additional control equipment } \\
\text { downstream. Not recommended for } \\
\text { batch operations. }\end{array}$ \\
\hline $\begin{array}{l}\text { Catalytic } \\
\text { Oxidation }\end{array}$ & $100-2000$ & $\begin{array}{l}1000- \\
100,000\end{array}$ & $90-95$ & $\begin{array}{l}\text { fixed bed } \\
20-250 \\
\text { fluidized } \\
35-220\end{array}$ & $\begin{array}{l}\text { fixed bed } \\
10-75 \\
\text { fluidized } \\
15-90\end{array}$ & $\begin{array}{l}\text { fixed bed } \\
13-115 \\
\text { fluidized } \\
20-125\end{array}$ & $\begin{array}{l}\text { Combustion } \\
\text { products }\end{array}$ & $\begin{array}{l}\text { Up to } 70 \% \text { energy } \\
\text { recovery is possible }\end{array}$ & $\begin{array}{l}\text { Thermal efficiency suffers with } \\
\text { swings in operating conditions. } \\
\text { Halogenated compounds may require } \\
\text { additional control equipment. } \\
\text { Certain compounds can poison the } \\
\text { catalyst (lead, arsenic, phosphorus, } \\
\text { chlorine, sulfur, particulate matter). }\end{array}$ \\
\hline Condensation & $>5000$ & $\begin{array}{l}100- \\
20,000\end{array}$ & $50-90$ & $10-80$ & $20-120$ & $22-130$ & Condensate & $\begin{array}{l}\text { Product recovery can } \\
\text { offset annual operating } \\
\text { costs }\end{array}$ & $\begin{array}{l}\text { Not recommended for materials with } \\
\text { boiling points }<100^{\circ} \mathrm{F} \text {. Condensers } \\
\text { are subject to scale buildup, which } \\
\text { can cause fouling. }\end{array}$ \\
\hline $\begin{array}{l}\text { Carbon } \\
\text { Adsorption }\end{array}$ & $20-5000$ & $\begin{array}{l}100- \\
60,000\end{array}$ & $90-98$ & $15-120$ & $10-35$ & $12-55$ & $\begin{array}{l}\text { Spent } \\
\text { carbon; } \\
\text { Collected } \\
\text { organic }\end{array}$ & $\begin{array}{l}\text { Product recovery can } \\
\text { offset costs. Can be } \\
\text { used as a concentrator } \\
\text { in conjunction with } \\
\text { another type of control } \\
\text { device. Works well } \\
\text { with cyclic processes. }\end{array}$ & $\begin{array}{l}\text { Not recommended for streams with } \\
\text { relative humidity }>50 \% \text {. Ketones, } \\
\text { aldehydes, and esters clog the pores } \\
\text { of the carbon, decreasing system } \\
\text { efficiency. }\end{array}$ \\
\hline Absorption & $500-5000$ & $\begin{array}{l}2000- \\
100,000\end{array}$ & $95-98$ & $15-70$ & $25-120$ & $27-130$ & $\begin{array}{l}\text { Waste- } \\
\text { water; } \\
\text { Captured } \\
\text { particulate }\end{array}$ & $\begin{array}{l}\text { Product recovery can } \\
\text { offset annual operating } \\
\text { costs. }\end{array}$ & $\begin{array}{l}\text { Might require exotic scrubbing } \\
\text { media. Design could be difficult in } \\
\text { the event of lack of equilibrium data. } \\
\text { Packing is subject to plugging and } \\
\text { fouling if particulates are in the gas } \\
\text { stream. Scale formation from the } \\
\text { absorbent-absorber interaction can } \\
\text { occur. }\end{array}$ \\
\hline $\begin{array}{l}\text { Photocatalytic } \\
\text { Oxidation: } \\
\text { Solar }\end{array}$ & $<1000$ & $<20,000$ & $90-99+$ & $60-320$ & $5-90$ & $15-140$ & $\begin{array}{l}\text { Oxidation } \\
\text { products }\end{array}$ & $\begin{array}{l}\text { Modular design. Low } \\
\text { energy and operating } \\
\text { cost. }\end{array}$ & $\begin{array}{l}\text { Solar availability approx. } 1 / 3 \text { due to } \\
\text { diurnal variations and weather. } \\
\text { Halogenated compounds may require } \\
\text { additional control equipment. } \\
\text { Catalyst fouling possible. }\end{array}$ \\
\hline $\begin{array}{l}\text { Photocatalytic } \\
\text { Oxidation: } \\
\text { Electric }\end{array}$ & $<1000$ & $<20,000$ & 90 - 99+ & $15-260$ & $5-100$ & $10-140$ & $\begin{array}{l}\text { Oxidation } \\
\text { products }\end{array}$ & Modular design & $\begin{array}{l}\text { Halogenated compounds may require } \\
\text { additional control equipment. } \\
\text { Catalyst fouling possible. }\end{array}$ \\
\hline
\end{tabular}

Note: $\mathrm{cfm}=$ cubic feet per minute, $35.3 \mathrm{cfm}=1 \mathrm{~m}^{3} / \mathrm{min}$ 


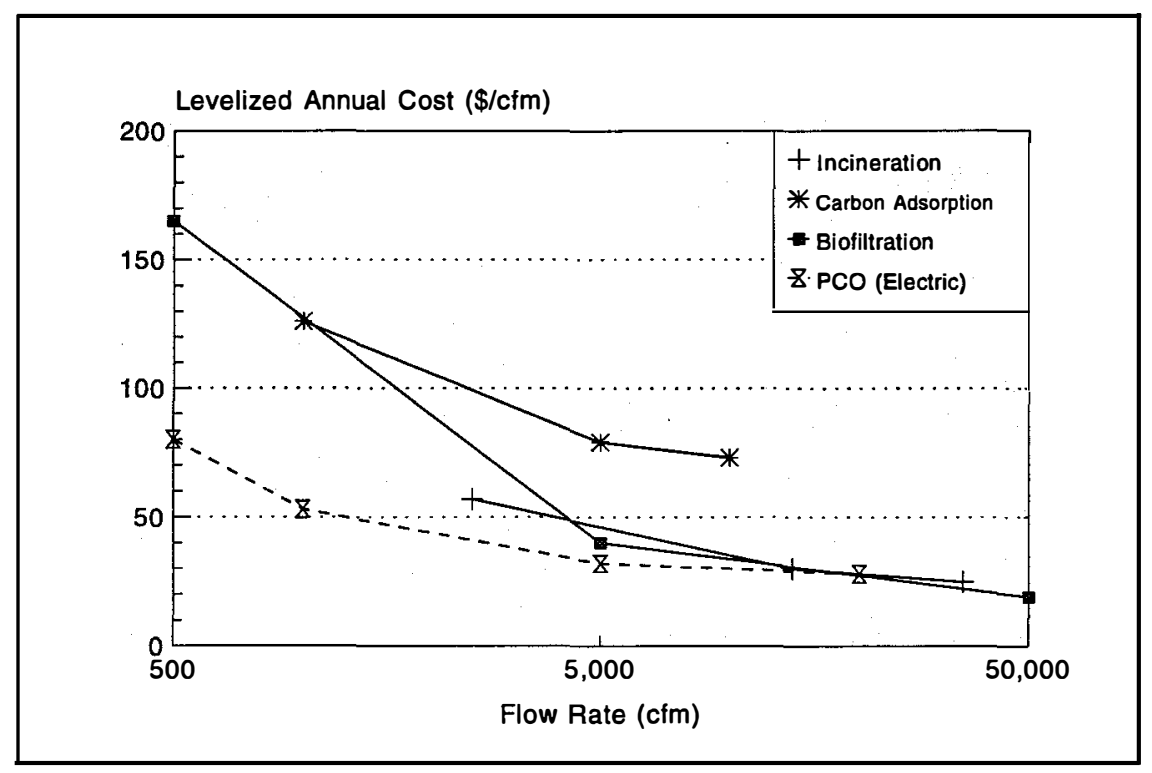

Figure 1: Cost of control technology versus flow rate. Values based on 500 ppm of a hydrocarbon pollutant. A hydrocarbon pollutant favors the incineration, adsorption, and biofiltration technologies (see text). Data for incineration, adsorption, and biofiltration technologies taken from reference [4].

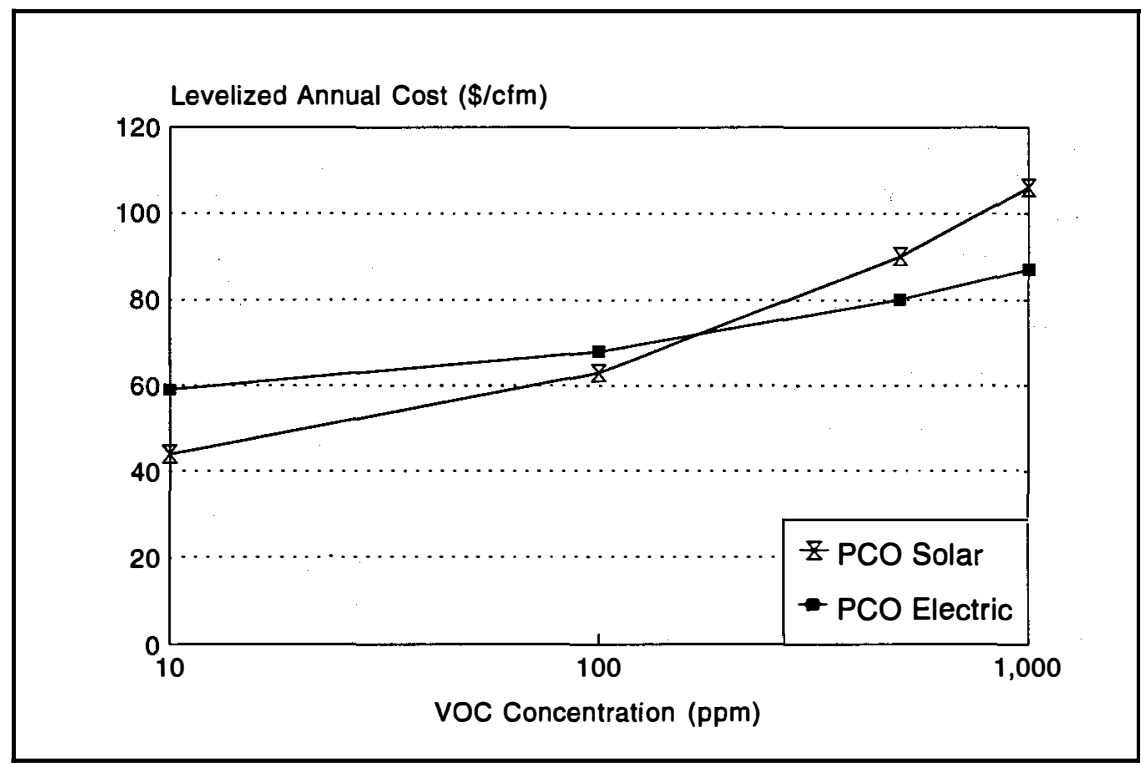

Figure 2: $\quad$ Cost of photocatalytic oxidation technology versus VOC pollutant concentration. Assumed apparent photoefficiency is $10 \%$ at 100 ppm, flow rate is $500 \mathrm{cfm}$. 